\title{
WANT BIRDS ABOUT HOME? Plant Wild Cherry Trees.
}

\author{
ART O. GELLERT, Yorkton
}

My home is right in the city of Yorkton. Until this year we were visited annually by 16 different species of wild birds, many nesting in the adjoining lots, only $50 \times 100$ feet, but thick with Choke Cherry, Pincherry and Saskatoon bushes. Last spring a new home appeared on this lct. It was cleared of all trees and equally absent were the many varieties of wild birds we had enjoyed these many years.

An Oriole pair, or their descendents having been building their hanging nests here for the past twenty years. They chose the tallest tree, a black poplar and although it may seem odd, they usually repaired the old nest. This tall poplar was half dry and quite often the Downy Woodpecker would tap for worms One year a Flicker nested in a hollow in this tree.

Yellow Warbiers were common visitors then and infrequently the American Goldfinch would honor us with a nesting - but this particular Goldfinch hasn't been in evidence for nearly ten years. Blackbirds always nested in the lot across the lane from the cherry stand and always fought with English Sparrows and with the Purple Martin's, nesting in the garage eves or in the 18 room birdhouse in the backyard. This spring a pair of Pintail Ducks tried to nest in the small slough in the lot across the lane but too many people disturbed them, and after a week of trying, they flew away. Robins had several nests in the yard maple trees. Here, for several years, there was one so low that we could watch the eggs and the ultimate hatching of them. This pair of Robins finally lost trust in us after a neighbor boy climbed the maple "just to see the eggs", and fell to the ground with nest, branch and all.

We have had House Wrens for several years but at times they shun our wren bird-houses, although we cleaned them yearly - but they do nest in the vicinity somewhere and we often watch them hunting for grubs for their young. The visits we had from the Ruby-throated Hummingbirds were attributed to the delphinium, hollyhock, and the apple trees in the yard. From our diningroom window my family had many thrilling sights watching the "helicopter" of birddom hover and flit about - forward and backward with only a few inches separating them from our point of vision. The hollyhocks and delphiniums grew close to the windows and were a natural screen for the tiny birds, so seldom seen at close range.

The birds mentioned were the most common and yearly appeared on the scene. Many others, travelling through, or possibly enticed by the small wild apples on one of the yard trees or dried choke-cherries on the bushes next to our yard, provided us with many thrilling sights - like a whole clothesline filled with Cedar Waxwings - a truly smooth and lovely looking bird, and not afraid, either. Then Then Chickadees were always present to battle over crusts on the snow.

But since the cherry trees disappeared the species visiting our home, this year, numbered less than five. It is true that clearing the land often means a greater loss to us than gain. Great thought should be given to the final result before complete acreages are cleared from boundary to boundary, with no thought of windbreaks or cover for birds. You, I and those to come will miss the awakening of the birds in the morning and their singing which gives to us that contented feeling of "being glad to be alive."

\section{ERRATA}

The U.S. Fish \& Wildlife Service have informed Dr. Stuart Houston that their previous report of one of $h$ is Black-crowned Night Harons having been recovered at Lesser Slave Lake, Alberta, was in error. Although the actual band had been submitted to Washington, their clerk had read the number incorrectly. The bird was a Malard banded in Alberta by Steve Brace. 